\title{
CHARACTERISTICS OF PORE-WATER PRESSURE RESPONSE IN SLOPES DURING RAINFALL
}

\author{
Alfrendo Satyanaga Nio ${ }^{[1]}$
}

\begin{abstract}
Field measurements of residual soil slopes are valuable for the assessment of slope stability during rainfall. Several residual soil slopes, which are predominantly unsaturated due to their deep groundwater table, were instrumented with tensiometer and rainfall gauge in order to study the response characteristics of the slopes during rainfall. Comprehensive field measurement results involving a large number of rainfall events are presented in the paper. The results show that the porewater pressures in all instrumented slopes increased in a similar fashion during rainfall, but at different magnitudes depending on soil type. The pore-water pressure response characteristics can then be used to estimate the variation in factor of safety of the slope during rainfall.
\end{abstract}

Keywords : Residual soil, Rainfall, Unsaturated, Tensiometer, Pore-water pressure.

\begin{abstract}
ABSTRAK
Penyelidikan dari kondisi tanah residual yang sebenarnya di lapangan sangat berharga untuk analisis stabilitas lereng selama hujan turun. Beberapa lereng yang mengandung tanah residual, di mana sebelumnya berada dalam kondisi tidak jenuh karena dalamnya muka air tanah, dipasangi tensiometer dan rainfall gauge untuk mempelajari sifat-sifat dari lereng tersebut pada waktu hujan. Hasil dari penyelidikan tanah di lapangan yang melibatkan pengukuran curah hujan dipresentasikan melalui journal ini. Hasil analisis menunjukkan bahwa semua tekanan air pori pada lereng yang dipasang tensiometer dan alat pengukur curah hujan, mengalami peningkatan yang sama, tetapi mempunyai perbedaan nilai yang tergantung dari jenis tanah pada lereng tersebut. Selanjutnya, sifat-sifat dari tekanan air pori dapat dipakai untuk memperkirakan faktor keamanan dari lereng selama hujan turun.
\end{abstract}

Kata kunci : Tanah residual, Rainfall, Unsaturated, Tensiometer, Pore-water pressure.

\section{INTRODUCTION}

Slope failures cause a major threat to both lives and property worldwide especially in regions of residual soils that are subjected to frequent heavy rainfalls. In areas of steep terrain that experience prolonged hot and dry periods followed by heavy rainstorms, slope failures continue to occur during or after rainfall.

In tropical and subtropical areas, rainfall-induced slope failures are closely related to the properties of the soil, the geometry of the slope, and the environmental factors (vegetation and weathering effects).

Almost all traditional slope stability analyses incorporate rainfall effects based on the assumption of saturated soil behaviour. However, this method cannot be applied to slopes under unsaturated conditions since some of the infiltration profiles may lead to the 
development of perched water zones near the surface of the slope, causing a decrease in unsaturated shear strength and slope failures.

This paper is intended to examine the characteristics of pore-water pressure response during rainfall within two instrumented slopes in Singapore. The main factors affecting the stability of a slope are rainfall pattern, initial conditions within the slope (expressed either as initial pore-water pressure distribution within the slope) and hydrological parameters of the slopes.

\section{OVERVIEW OF THE STUDY AREA}

Field monitoring and investigation took place on the western part of Singapore. The slopes are called NTU-CSE and NTU-ANX, located in Nanyang Technological University (NTU), where its geological formation is referred to as sedimentary Jurong Formation (Pitts, 1984). An $11 \mathrm{~m}$ high rain tree, of the Samanea saman type (Rao and Wee, 1989), exists at the toe of the NTU-CSE slope, $2 \mathrm{~m}$ from the instrumentation area. Both slopes were covered by buffalo grass. Table 1 shows geometry and geological information of NTU-CSE and NTU-ANX slopes.

Five boreholes were drilled to a depth of $28 \mathrm{~m}$ in the NTU-CSE slope whereas two boreholes were drilled in the NTU-ANX slope (Rahardjo et al., 2000). The borehole information and the laboratory tests were combined to produce a simplified slope profile (Figure 1). The hydrologic and engineering properties of top soils are summarized in Table 2. The soil profile of both slopes consists of two layers and bedrock. Almost all the layers contain silt and clay. The higher value of permeability in the NTU-CSE slope reflects the coarser particle size in this site than in the NTU-ANX slope.

\section{FIELD INSTRUMENTATION PROGRAM}

The in-situ measurements of negative pore-water pressure were carried out using JetFill tensiometers. These tensiometers have capability to measure negative pore-water pressures up to -100 $\mathrm{kPa}$. The NTU-CSE slope has six rows of tensiometer while the NTUANX slope only has three rows of tensiometer, which are spaced $3 \mathrm{~m}$ apart. Each row comprises five Jet-Fill tensiometers, which are situated $0.5 \mathrm{~m}$ apart and installed at depths of $0.5,1.1,1.7,2.8$, and $3.2 \mathrm{~m}$.

The schematic diagram of the instrument position is shown in Figures 2 and 3. Pressure transducers were installed at the top of the tensiometer and they were connected to a Fluke TM Hydra 2365A data bucket and a Grayhill Inc. data acquisition system in the NTU- 
CSE and NTU-ANX slopes, respectively. The measurements were collected every 4 hours during dry period.

Rainfall was recorded at both slopes using a tipping-bucket (Handar 444A) rain gauge. Once a rainfall event started, the data acquisition systems on both slopes would start collecting measurements from all instruments at intervals of $10 \mathrm{~min}$. The fluctuations of the groundwater level during wet and dry periods were monitored with the Cassagrande piezometer with a ceramic tip and PVC riser tubing. A detailed description of instrumentation within NTU sites can be found in Gasmo et al. (1999) and Tsaparas (2001).

Table 1. Site investigation of two instrumented slopes in NTU

\begin{tabular}{lll}
\hline Variable & NTU-CSE & NTU-ANX \\
\hline Slope height $(\mathrm{m})$ & 7.1 & 3.3 \\
\hline Slope angle $\left(^{\circ}\right)$ & 27 & 29 \\
\hline $\begin{array}{l}\text { Vegetation cover } \\
(\%)\end{array}$ & 100 & 100 \\
\hline Soil type (USCS)* & $\begin{array}{c}\text { CL to SC- } \\
\text { CL }\end{array}$ & CL-ML \\
\hline
\end{tabular}

*USCS = Unified Soil Classification System

Table 2. Soil properties in top $3 \mathbf{m}$ of investigated slopes

\begin{tabular}{lll}
\hline Properties & NTU-CSE & NTU-ANX \\
\hline Bulk density, $\rho$ & 2.10 & 2.00 \\
\hline $\begin{array}{c}\text { Water content, } \mathrm{w} \\
(\%)\end{array}$ & 19 & 22 \\
\hline $\begin{array}{c}\text { Liquid Limit, LL } \\
\text { (\%) }\end{array}$ & 36 & 45 \\
\hline $\begin{array}{c}\text { Plasticity Index, PI } \\
(\%)\end{array}$ & 14 & 19 \\
\hline Fines (\%) & 58 & 74 \\
\hline $\begin{array}{c}\text { Effective cohesion, } \\
\text { c' }\end{array}$ & 13.8 & 5.0 \\
\hline $\begin{array}{c}\text { Effective angle of } \\
\left.\text { friction, } \phi{ }^{\circ}{ }^{\circ}\right)\end{array}$ & 40 & 32 \\
\hline $\begin{array}{c}\text { Permeability, } \mathrm{k}_{\mathrm{s}} \\
\left(\mathrm{m} . \mathrm{s}^{-1}\right)\end{array}$ & $7.8 \times 10^{-8}$ & $3.5 \times 10^{-9}$ \\
\hline
\end{tabular}

Note : Soil physical and engineering properties were obtained from an average of 7 to 9 samples, and soil hydrological properties were obtained from an average of 2 to 4 samples. 


\section{PORE-WATER PRESSURE VARIATION DUE TO RAINFALL}

The average monthly total rainfall on both NTU-CSE and NTU-ANX slopes is 102 mm. October to December 1999 was the wettest period with $615 \mathrm{~mm}$ of total rainfall and April to June 2000 was the driest period of the year with $279 \mathrm{~mm}$ of total rainfall.
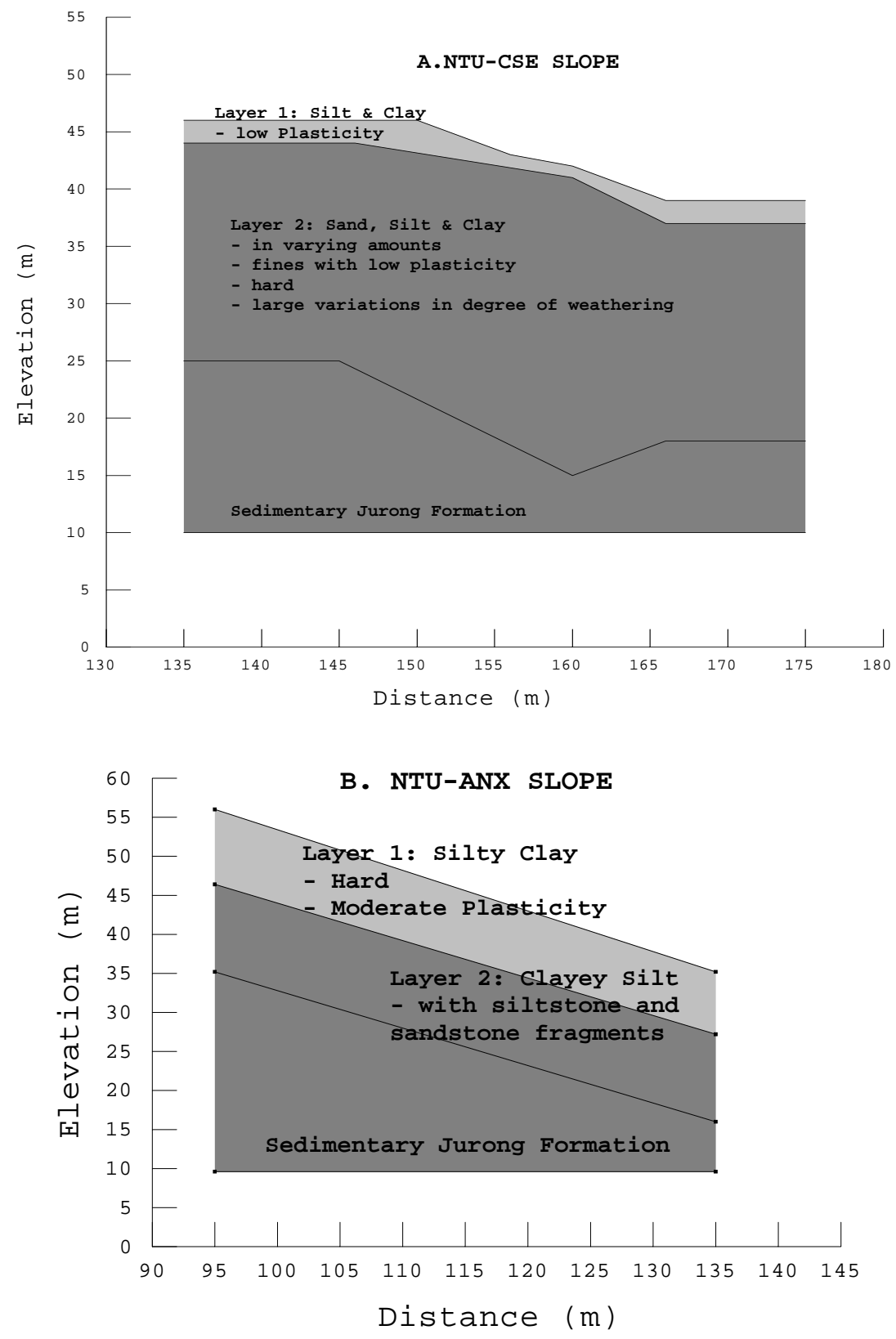

Figure 1. Soil profile of the instrumented slope: (a) NTU-CSE (b) NTU-ANX 


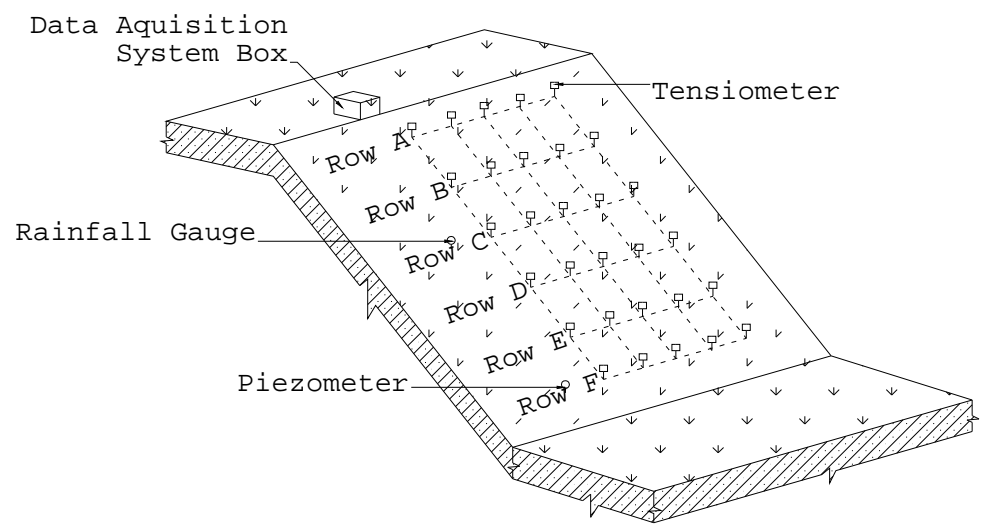

Figure 2. Location of instrumentation installed in NTU-CSE slope

The development of the pore-water pressures with time for the instrumented NTUCSE and NTU-ANX slopes as measured by the tensiometers are presented in Figures 4, 5, and 6. The figures also present the corresponding rainfall data in order to study the development of pore-water pressures at each depth due to infiltration.

During the monitoring period, negative pore-water pressure as high as $-90 \mathrm{kPa}$ was observed at depth of $0.5 \mathrm{~m}$ in the NTU-CSE slope after a long dry period. Positive porewater pressures were observed at all soil depths in the NTU-ANX slope after a significant rainfall, but they were not observed at shallow depths in the NTU-CSE slope.



Figure 3. Location of instrumentation installed in NTU-ANX slope

Figures 4, 5 and 6 also show that the initial pore-water pressure has significant effect on changes in pore-water pressure during rainfall. It is observed that the more negative the initial pore-water pressure is, the higher will be the change in the pore-water pressure for a given rainfall. In general, the pore-water pressures in the NTU-ANX slope are higher or 
more positive than those in the NTU-CSE slope. As a result, during a particular rainfall the changes in the pore-water pressure in the NTU-ANX slope are not as high as the pore-water pressure changes in the NTU-CSE slope.

The changes in pore-water pressure in the NTU-CSE and NTU-ANX slopes at depths of 0.5, 1.1, and $1.7 \mathrm{~m}$ due to a significant amount of rainfall are shown in Figures 7 and 8, respectively. The pore-water pressure data are taken from tensiometer readings on 25 March 2000, 26 March 2000 and 28 March 2000 in row A in the NTU-CSE and NTU-ANX slopes. The first reading was taken on 25 March 2000 before rainfall occured. The next reading was taken at the end of the rainfall event of $50 \mathrm{~mm}$. The last pore-water pressure data were taken two days after the rainfall stopped.

\section{DISCUSSION}

Initially, pore-water pressure was $-18 \mathrm{kPa}$ at depth of $0.5 \mathrm{~m}$ in the NTU-CSE slope. On the next day, it increased rapidly to $-9 \mathrm{kPa}$ after the rainfall ended (see Figure 7). The rate of increase appeared to decrease for tensiometer readings at deeper depths. Two days after the rainfall stopped, pore-water pressure decreased to $-12 \mathrm{kPa}$ since water had percolated down to deeper depths. This trend was similar at all depths in the NTU-CSE slope.

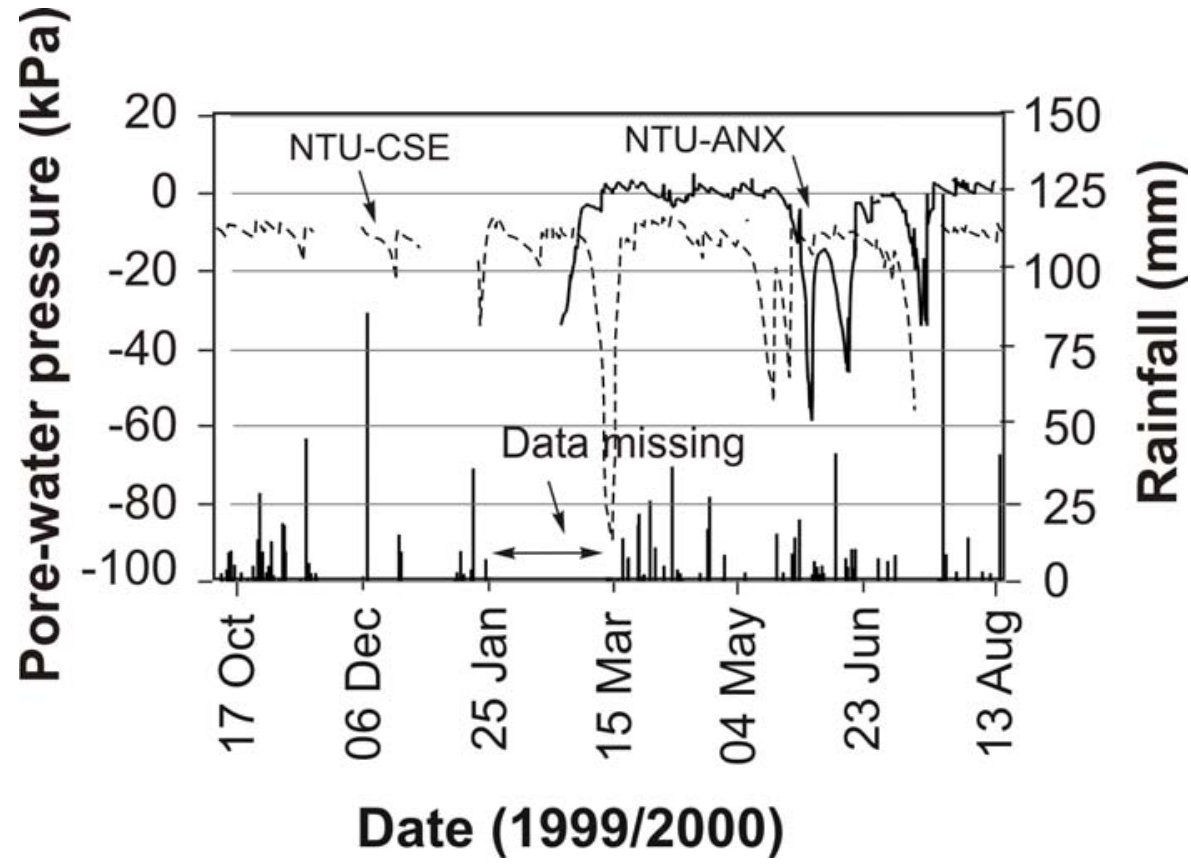

Figure 4. Time series of rainfall and pore-water pressure in NTU-CSE and NTU-ANX slopes at depth $0.5 \mathrm{~m}$ 


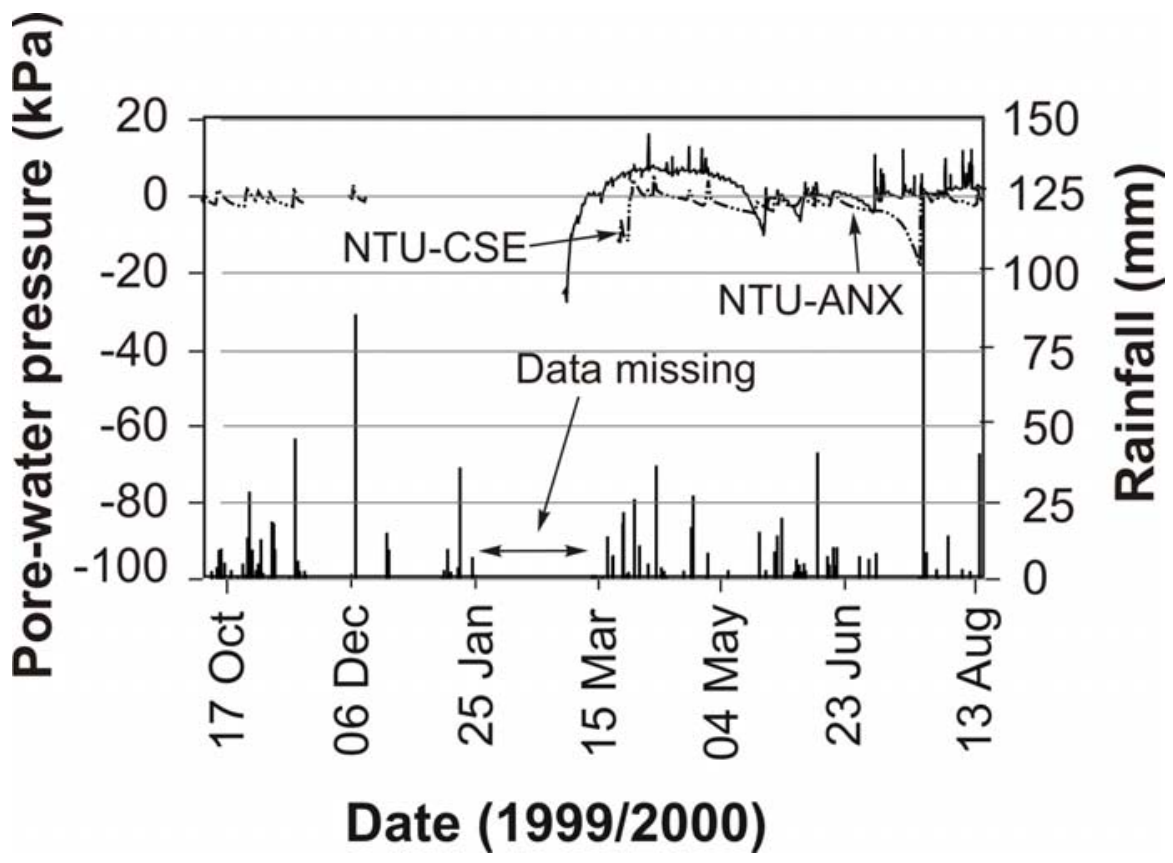

Figure 5. Time series of rainfall and pore-water pressure in NTU-CSE and NTU-ANX slopes at $1.1 \mathrm{~m}$

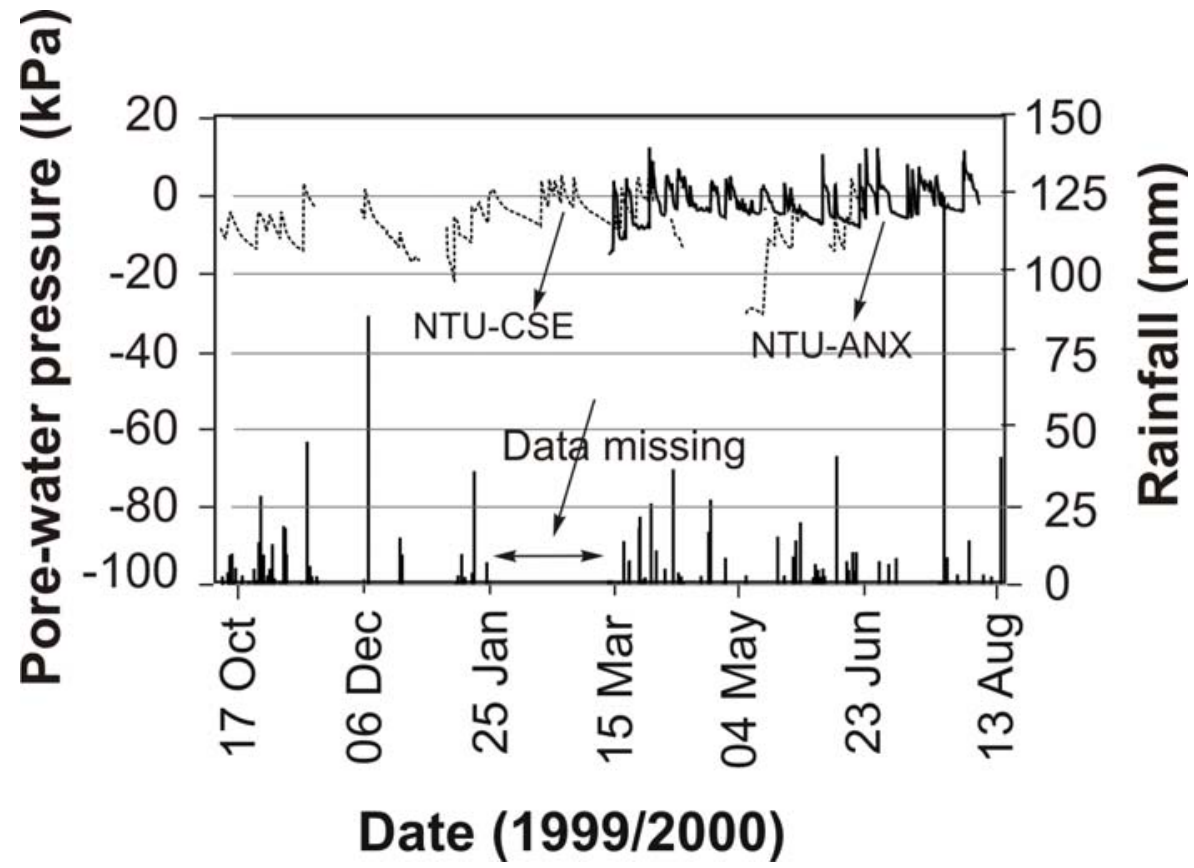

Figure 6. Time series of rainfall and pore-water pressure in NTU-CSE and NTU-ANX slopes at $1.7 \mathrm{~m}$

In the NTU-ANX slope, the initial pore-water pressure was higher than the one in the NTU-CSE slope. It can be observed from Figure 8 that there was an increase in the porewater pressure at the end of rainfall although the rate was slower than the one in the NTU- 
CSE slope. However, in the NTU-ANX slope, the increase in pore-water pressure was higher at depths of 1.1 and $1.7 \mathrm{~m}$. Then the rate decreased again at depth of $2.8 \mathrm{~m}$. This trend occurred due to the lower permeability of the soil in the NTU-ANX than that in the NTUCSE slope. Rain water needs a longer time to reach greater depths and as a result, a perched water table might have developed.

Figures 7 and 8 also show that pore-water pressure in the NTU-CSE slope appeared to increase with depth. Meanwhile, the pore-water pressure in the NTU-ANX slope remained essentially constant with depth. This occurred due to the fact that water flowed down faster through the soil layer within the NTU-CSE slope due to the coarser particle size of the soils as opposed to those in the NTU-ANX slope.

It is observed in Figures 4, 5 and 6 that the increase in pore-water pressure does not seem to be proportional to the amount of rainfall. Therefore, a correlation between the increase in pore-water pressure and the amount of daily rainfall in the NTU-CSE and NTUANX slopes was examined. The analyses were performed using the rainfall data from 15 March 2000 until 13 August 2000 since the instrumentation readings for the NTU-ANX slope were taken within this period.

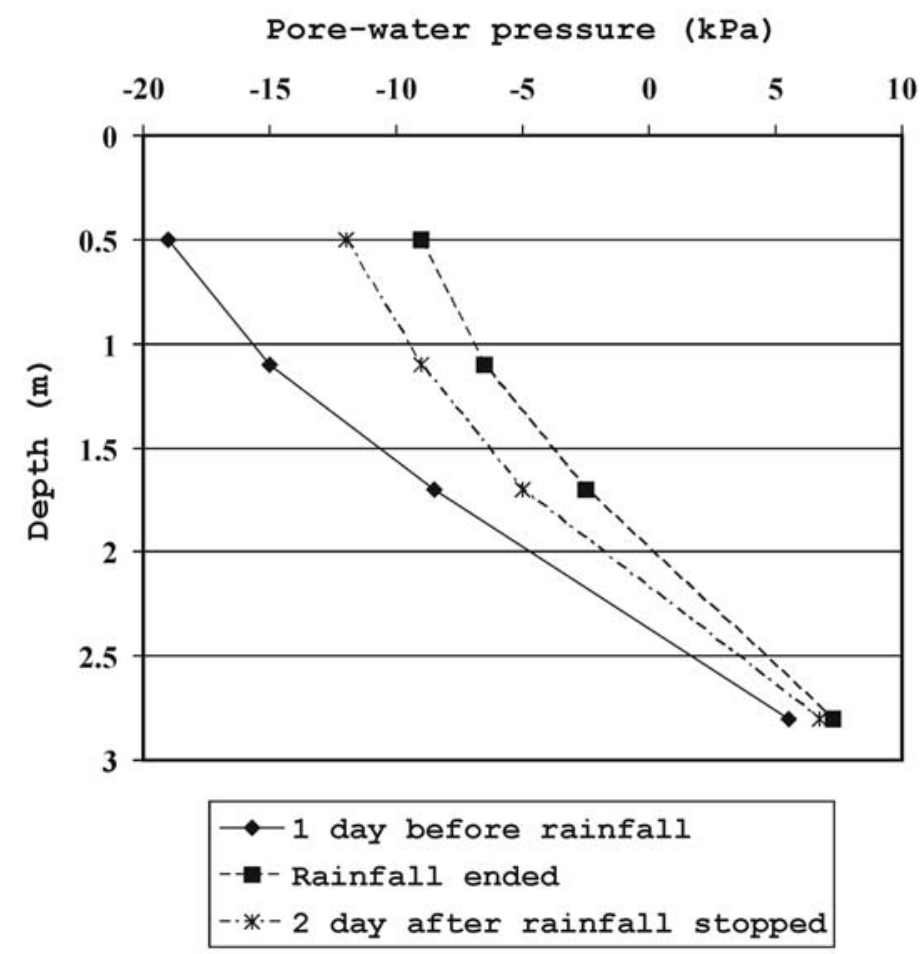

Figure 7. Pore-water profiles in row A of NTU-CSE slopes 


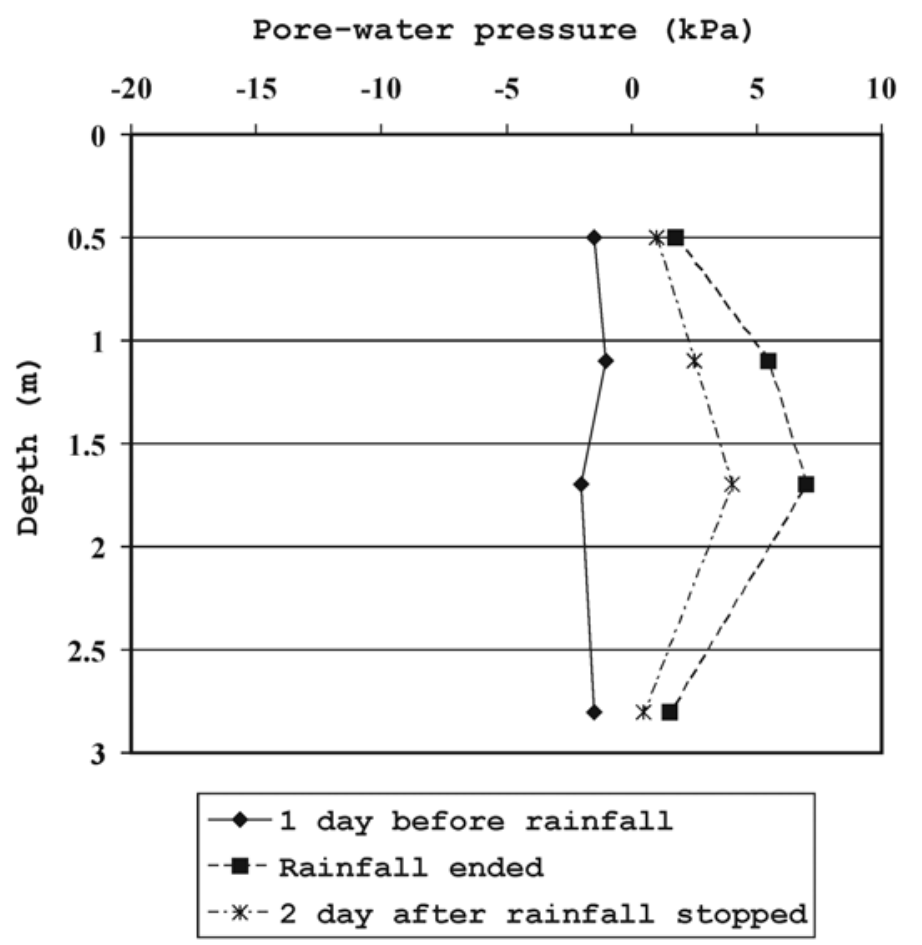

Figure 8. Pore-water profiles in row A of NTU-ANX slopes

The analyses were conducted using tensiometer measurements from three different depths, such as: $0.5 \mathrm{~m}, 1.1 \mathrm{~m}$ and $1.7 \mathrm{~m}$. The tensiometer measurements from greater depths are insufficient for developing a relationship between the increase in pore-water pressure and daily rainfall. The analyses were performed by taking the algebraic difference in pore-water pressure before and after the rainfall event. Figures 9 and 10 show the increase in pore-water pressure as a function of the daily rainfall amount monitored at the NTU-CSE and NTUANX slopes, respectively. A semi logarithmic form of correlation between increase in pore water pressure and daily rainfall amount could be developed using significant daily rainfalls and corresponding increases in pore-water pressure. The parameters for the correlations were obtained by the non-linear regression method (Wilkinson, 1986).

The relative increase in pore-water pressure seems to increase rapidly with the increase of daily rainfall at all depths in the NTU-CSE slope, but then the rate of increase tends to decline at larger daily rainfall amounts. At depth of $0.5 \mathrm{~m}$, the average values of the increase in pore-water pressure are higher than those at deeper depths in the NTU-CSE slope. However, the slopes of the regression lines show a similar trend for all depths. The regression lines indicate that the increase in pore-water pressure tends to slow down after a 
daily rainfall of $20 \mathrm{~mm}$ for all depths in the NTU-CSE slope. The increase in pore-water pressure achieves its maximum as the soil approaches saturation.

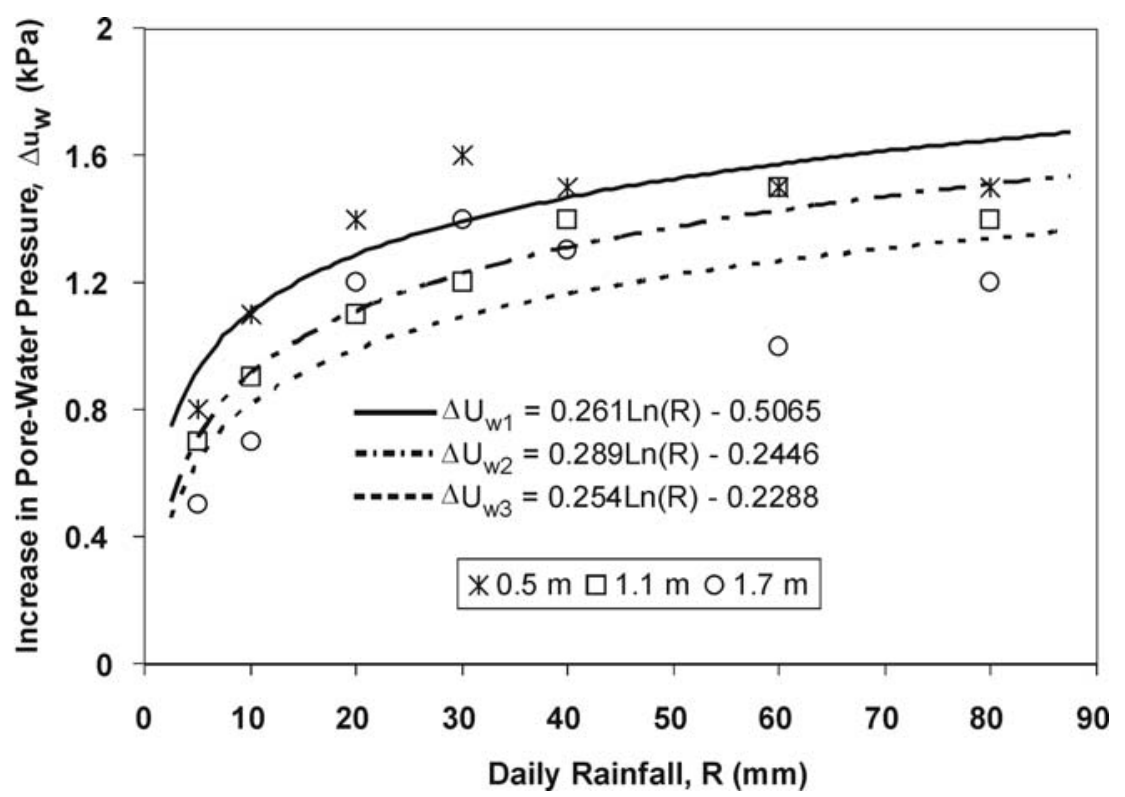

Figure 9. Relationship between increase in pore-water pressure and daily rainfall amount in NTU-CSE slope

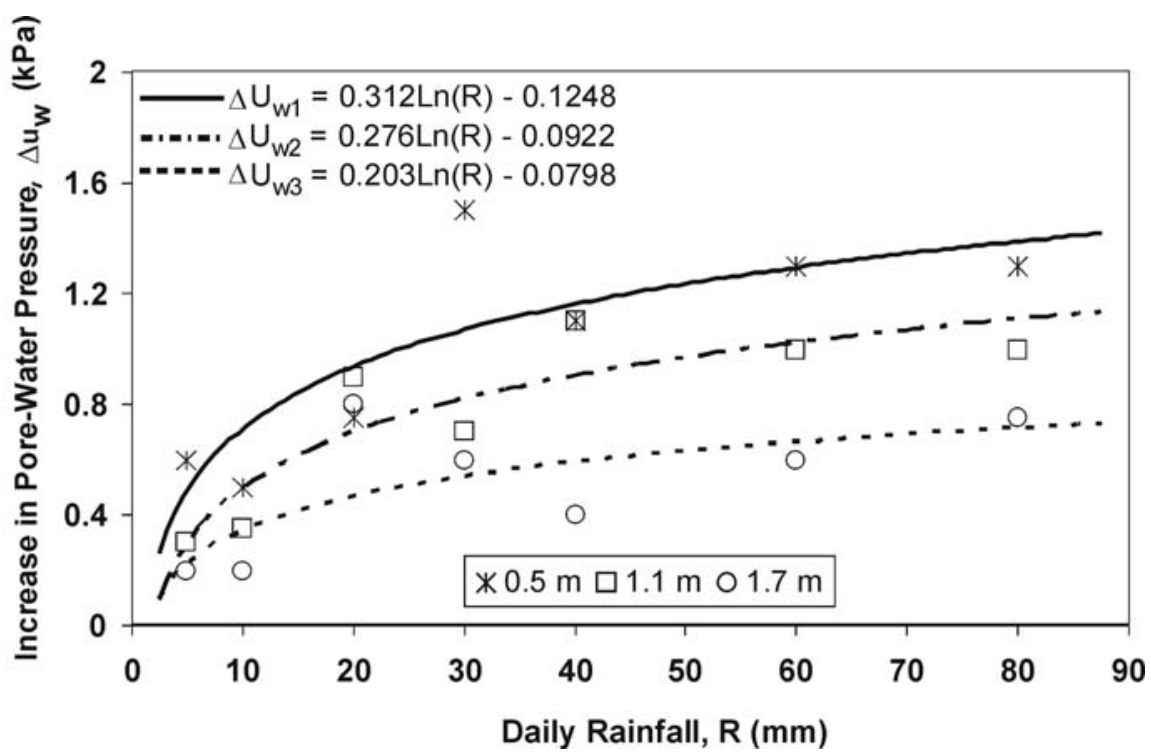

Figure 10. Relationship between increase in pore-water pressure and daily rainfall amount in NTU-ANX slope

Note:

$\Delta \mathrm{u}_{\mathrm{w} 1} \quad=$ increase in pore-water pressure in depth of $0.5 \mathrm{~m}$

$\Delta \mathrm{u}_{\mathrm{w} 2} \quad=$ increase in pore-water pressure in depth of $1.1 \mathrm{~m}$

$\Delta \mathrm{u}_{\mathrm{w} 3} \quad=$ increase in pore water pressure in depth of $1.7 \mathrm{~m}$

$\mathrm{R} \quad=$ amount of daily rainfall 
In the NTU-ANX slope, initially the increase in pore-water pressure at all depths increases quickly and then starts to decline after a daily rainfall of $30 \mathrm{~mm}$. The rates of increase in pore-water pressure in the NTU-ANX slope are not the same at the different depths for a given daily rainfall since the initial pore-water pressure is more negative at shallower depths.

Figures 9 and 10 show that the rate of increase in pore-water pressure in the NTUCSE slope is faster than the rate of increase in pore-water pressure in the NTU-ANX slope. This could be attributed to the higher permeability of soils in the in NTU-CSE slope than the permeability of soils in the NTU-ANX slope. As a result, the infiltration rate in the NTUCSE slope is faster than the infiltration rate in the NTU-ANX slope.

In addition, the maximum increase in pore-water pressure in the NTU-CSE slope is higher than the maximum increase in pore-water pressure in the NTU-ANX slope since the initial pore-water pressures in the NTU-CSE slope are generally more negative than initial pore-water pressures in the NTU-CSE slope. As a general observation, the more negative the initial pore-water pressure is, the higher will be the change in the pore-water pressure for a given rainfall.

\section{CONCLUSIONS}

Two residual soil slopes from the sedimentary Jurong Formation in Singapore were instrumented for field monitoring during dry and rainy periods. The analysis of the porewater pressure changes show that the changes in pore-water pressure during rainfall are not entirely dependent on the total rainfall amount, but also on the initial pore-water pressure values. If the initial pore-water pressure has a low value, then it will experience a relatively high increase in pressure during a rainfall event. The pore-water pressure may remain constant after reaching its peak value. Analyses of data from these two slopes illustrate that a relationship between the increase in pore-water pressure and daily rainfall amount can be developed for a particular slope with given soil properties.

\section{ACKNOWLEDGEMENTS}

This study was supported by a research grant from the National Science and Technology Board, Singapore (Grant NSTB 17/6/16: Rainfall-Induced Slope Failures). The writers are deeply grateful for the assistance from Geotechnics Laboratory staff, School of 
Civil and Environmental Engineering, Nanyang Technological University, Singapore, during setup and data collection.

\section{REFERENCES}

1. Fredlund, D.G, and Rahardjo, H. (1993), Soil Mechanics for unsaturated soils, John Wiley \& Sons Inc., New York.

2. Gasmo, J.M., Rahardjo, H., Leong, E.C. (2000), Infiltration effects on stability of a residual soil slope, Computer and Geotechnics 26, 145-165.

3. Lim, T.T., Rahardjo, H., Chang, M.F., \& Fredlund, D.G. (1996), Effect of rainfall on matric suctions in a residual soil slope, Canadian Geotechnical Journal, 33: 618-628.

4. Pitts, J., and Cy, S. (1987), In situ soil suction measurements in relation to slope stability investigations in Singapor, E.T. Hanrahan, T.L. L. Orr, and T.F. Widdis, eds., Pro., $9^{\text {th }}$ European Conf. on soil mechanics and foundation engineering. Vol. 1, Balkema, Rotterdam, The Netherlands, 79-82.

5. Rahardjo, H. (2000), Rainfall-induced slope failures, NSTB Rep. 17/6/16, School of Civil and Structural Engineering, Nanyang Technological University, Singapore.

6. Rahardjo, H., Leong, E.C., Deutsher, M.S., Gasmo, J.M., and Tang, S.K. (2000), Rainfall-induced slope failures, Geotechnical Engineering Monograph 3, NTU-PWD Geotechnical Research Centre, Nanyang Technological University, Singapore. ISBN 81-04-2928-2.

7. Rahardjo, H., Lee, T.T, Leong, E.C. \& Rezaur, R.B. (2005), Response of a residual soil slope to rainfall, Canadian Geotechnical Journal 42: 340-351.

8. Rao, A.N., and Wee, Y.C. (1989), Singapore trees, Singapore Institute of Biology, Jin Jin Printing Industry, Singapore. pp 287-288.

9. Rezaur, R.B., Rahardjo, H., Leong, E.C. \& Lee, T.T. (2003), Hydrologic behaviour of residual soil slopes in Singapore, Journal of Hydrologic Engineering, Vol. 8, No. 3, 133-144.

10. Tsaparas, I., Rahardjo, H., Toll, D.G., \& Leong, E.C. (2003), Infiltration characteristics of two instrumented residual soil slopes, Canadian Geotechnical Journal 40: 1012-1032. 
11. Tsaparas, I. (2002), Field measurements and numerical modelling of infiltration and matric suctions within slopes, $\mathrm{PhD}$ Thesis, University of Durham, Durham, United Kingdom.

12. Wilkinson, L. (1986), Systat: The system of statistics, SYSTAT Evanston III.

[1] Alfrendo Satyanaga Nio, Ir., M.Sc., Geotechnics Laboratory Staff, School of Civil and Environmental Engineering, Nanyang Technological University, Singapore. 